(1)

George Fox

UNIVERSITY
Digital Commons @ George Fox University

2017

Relationships with Families: Have Educators Overlooked a Critical

Piece of the Puzzle?

Karen S. Buchanan

Thomas D. Buchanan

Follow this and additional works at: https://digitalcommons.georgefox.edu/soe_faculty

Part of the Education Commons 


\title{
Relationships with families: \\ Have educators overlooked \\ a critical piece of the puzzle?
}

\author{
Karen Buchanan and Thomas Buchanan
}

George Fox University, USA

\begin{abstract}
While the importance of a professional teacher's collaboration with diverse families is clearly highlighted in the US Department of Education's Every Student Succeeds Act (ESSA) and in US teaching standards, research consistently reports that teachers feel unprepared to do this aspect of their work. The failure of the teaching profession to grow in partnering with families is a persistent and puzzling challenge in education. In this article, we argue that educators often overlook a critical piece of that puzzle. A foundational step in building effective partnerships with families is the development of relationships with parents. A careful review of the literature indicates that these relationships require intentional development. We offer specific strategies around six key concepts, drawn from the literature, for use by in-service and pre-service teachers. These strategies hold promise to improve professional practice through the building of meaningful relationships with families.
\end{abstract}

\section{Keywords}

Family collaboration, family engagement, parent partnerships, raising, relationship, relationship building

Standards for accomplished teachers and the Every Student Succeeds Act (ESSA), the United State's prominent educational legislation, clearly highlight the importance of a teacher's work with families on behalf of a child's academic growth and well-being. However, research consistently reports that teachers, both in-service and pre-service, feel unprepared to do this work (Casper, 2011; Epstein \& Sanders, 2006; Hiatt-Michael, 2001; Patte, 2011; Sewell, 2012). The 2006 MetLife survey of 1001 public school teachers reports that 'teachers consider engaging and working with parents as their greatest challenge and the area they were least prepared to manage during their first year' (Harvard Family Research Project, 2006, p. 1). Five years later, the 2011 MetLife survey noted, 'parent and community engagement has increased but remains a challenge for many schools' (Markow, Macia, \& Lee, 2013, p. 14). Data from this survey reveal that ratings of parent

\section{Corresponding author:}

Karen Buchanan, Department of Educational Leadership, George Fox University, 414 N Meridian St, Newberg, OR 97I32, USA.

Email: kbuchana@georgefox.edu 
engagement are highest for elementary school and generally are lower at each subsequent school level, from middle to high school. That same year, Epstein (2011) reported that little progress had been made in the last 20 years in the area of teacher and family collaboration. Teachers have found authentic partnerships with families to be a puzzling challenge.

It is time to look at this puzzling but important aspect of teacher practice with fresh eyes and consider new ways of thinking about the work between families and teachers. Tran (2014) suggests that one step in promoting academic success, for kindergarten through grade $12(\mathrm{~K}-12)$ students, is to purposely establish shared partnerships between the school and family. While the literature often talks in broad terms about shared or collaborative partnerships, these reciprocal relationships do not just happen because we name them; they take intentional development. Amatea (2009) states that her experiences have led her to believe that 'developing strong working relationships with the families of students is not only a nice activity, but also a necessary step for developing effective ways of reaching and teaching all students' (p. 17). Teachers' lack of attention to the knowledge, skills, and attitudes required to lay the foundation for collaborative relationships may account for the slow progress our field is making in this area of teacher practice. In this article, we argue that educators often overlook the importance of building meaningful relationships with families, to the detriment of supporting sustained and meaningful partnerships. The building of meaningful relationships with families is the overlooked piece of the puzzle. We propose that preparing teachers to build strong relationships with families holds promise to improve professional practice.

We begin by examining what already exists in US teaching standards; relationship building is part of professional expectations for teacher practice. Next, we explore the literature around relationship building and teachers' work with families. Finally, we propose a next step for the profession as we seek to improve professional practice with families. We recommend teacher development in practical relationship building skills and propose a set of concepts and strategies that teachers can acquire and use to improve their effectiveness with families.

\section{Examining the teaching standards}

US teacher standards are rooted in current research and serve as a roadmap for the field. The standards influence policy and define quality work for teachers. A content analysis, around the concept of family involvement/engagement, with two prominent sets of teaching standards reveals that relationship with families is a key element of proficient practice. Our examination of these standards begins with the Interstate Teacher Assessment and Support Consortium (InTASC) Model Core Teaching Standards.

\section{InTASC}

The InTASC (2011) standards greatly influence education in the United States. They are designed to guide 'states, districts, professional organizations, teacher education programs, teachers, and others as they develop policies and programs to prepare, license, support, evaluate, and reward today's teachers' (p. 7). The 2011 InTASC Model Core Teaching Standards serve as a framework for K-12 teachers across all grade levels and content areas. They describe what teachers should know and be able to do to improve student achievement; they place particular emphasis on meeting the needs of diverse student populations. The introduction to the standards states,

To do this effectively, teachers must have a deeper understanding of their own frames of reference (e.g., culture, gender, language, abilities, ways of knowing), the potential biases in these frames, and their impact on expectations for and relationships with learners and their families. (InTASC, 2011, p. 3) 
Crossing 7 of the 10 InTASC standards is the key theme of Families and Communities. The following teacher knowledge, skill, and attitudes are identified as elements of this key theme: understand family assets, respect family background/culture, collaborate with the family, value family input, engage the family, sustain ongoing communication with the family, and build relationships with students and families. Teachers' relationships with families are part of professional practice. The InTASC (2011) Standards are designed to be compatible with a second set of US standards, the National Board for Professional Teaching Standards (NBPTS).

\section{NBPTS}

Since its inception in 1987, the NBPTS has been the profession's vehicle for defining and recognizing accomplished teaching in the United States. In 1989, NBPTS articulated Five Core Propositions for Teaching in a policy piece entitled, What Teachers Should Know and Be Able to Do (NBPTS, 1989). These propositions undergird the standards. Proposition number five, Teachers are Members of Learning Communities, describes the professional relationships that teachers have within the school, the professional knowledge of school and community resources, and teachers' collaborative work with parents. NBPTS has created standards for what accomplished teachers should know and be able to do in 25 certificate areas that cross all age levels and content areas.

A content analysis of the NBPTS standards reveals specific professional practices related to a teacher's work with families. The notion of parents as partners and teachers building collaborative partnerships with families cross nearly all age levels and core content areas. The middle childhood (ages 7-12) and early childhood (ages 3-8) standards provide the greatest detail regarding partnerships; they talk about types and responsibilities associated with family relationships.

The Middle Childhood Generalist Standards standard six, Partnership and Outreach, clearly identifies relationships as an important aspect of teacher/family partnerships. Standard six says, 'accomplished teachers establish and maintain partnerships with families and the greater community to enhance teaching and support for student learning' (NBPTS, 2012b, p. 48). An explanation of the standards elaborates, 'they (accomplished teachers) keep families informed regarding their children's progress and collaborate with families purposefully to build relationships that will support, motivate, and improve students' learning' (NBPTS, 2012, p. 48). 'They work to develop trusting relationships in which parents see themselves as equal partners in their children's education' (NBPTS, 2012, p. 49). Relationship is identified as a key component of establishing and maintaining partnerships with families.

In the Early Childhood Generalist Standards for ages 3-8, standard two - Partnering with Families and Communities, there is a clear expectation that teachers value, initiate, and maintain relationships with families. The standard states, 'Accomplished early childhood teachers work reciprocally with families and community partners to support each child's development and learning and to advocate for young children and their families' (NBPTS, 2012, p. 27). An accompanying explanation of the standard says, 'accomplished early childhood generalists value, initiate, and maintain respectful and open relationships with families and community partners' (NBPTS, 2012, p. 27). The critical importance of relationship building is then emphasized in the following clear statement: 'accomplished early childhood teachers understand that establishing reciprocal communication and relationships of trust with families of young children is essential to successful collaboration' (NBPTS, 2012, p. 29). These standards emphasize the nature of the relationship with families as being open, respectful, reciprocal, and relationships of trust. 
Relationship and/or partnership with families are present as a strong expectation for teachers in both InTASC and NBPTS standards. While standards set the expectation for teacher work, the research literature indicates that what is currently happening in the field is less than ideal.

\section{Evolving notions of partnership}

Tran (2014) chronicles the changing definitions and notions of parent involvement over the last 20 plus years. Overtime, educators' notions of partnerships between home and school have moved from a participation paradigm, to a collaboration paradigm, and currently to an engagement paradigm (Harris \& Goodall, 2008). There has been a shift in the ways in which teachers and schools work with families: 'This shift involves a move from a traditional focus on parent involvement to a strategic emphasis on family partnering where educational success is viewed as a shared responsibility with families playing a critical role' (Miller, Lines, Sullivan, \& Hermanutz, 2013, p. 150). Halgunseth, Peterson, Stark, and Moodie (2009) discuss a comprehensive definition of partnerships from a programmatic perspective. Their work goes a step further and moves the notion of family and school interaction to an engagement paradigm and includes family participation in decision-making related to the child's education, consistent two-way communication, collaboration and exchange of knowledge, creating and sustaining learning activities at home, home environments that value learning, and systems for promoting family engagement (Halgunseth,et al.,, 2009). A study conducted by Harris and Goodall (2008) in the United Kingdom indicates that while parent involvement can bring some social and community benefits, it is engagement that makes the difference in improved achievement for children.

It is significant to note the shift in the literature from 'parent' to the more inclusive term of 'family'. This acknowledges the variety of individuals that play central roles in the care and education of children (Tran, 2014). These individuals include but are not limited to grandparents, siblings, aunts, uncles, caregivers, foster parents, and friends (Tran, 2014).

This literature indicates abundant evidence that students' benefit and achievement increases when families collaborate with teachers (Beltran, 2012; Christenson \& Reschly, 2010; Dorfman \& Fisher, 2002; Epstein, 2011; Henderson \& Mapp, 2002; Henrich \& Gadaire, 2008; Hiatt-Michael, 2010; Van Voorhis, Maier, Epstein, \& Lloyd, 2013; Weiss, Caspe, \& Lopez, 2006). Benefits for learners go beyond academic achievement to greater academic motivation, grade promotion, and increased social-emotional skills across all children, including those from diverse socioeconomic and ethnic backgrounds (Christenson, 2000; McWayne, Hampton, Fantuzzo, Cohen, \& Sekino, 2004; Mantzicopoulos, 2003).

While the construct of school-home relationships is clearly present in professional standards, the notion of a teacher's relationship with family as a key element in the building of effective partnerships appears to be under-represented in the aforementioned school-home literature that has influenced the field for the last several decades. However, literature more intently focused on diverse learners and students from economically disadvantaged homes places an emphasis on twoway relationships between school and home.

\section{Importance of two-way relationships}

There is a growing body of literature that describes the challenging nature of working with families that come from increasingly diverse cultures and ethnicities (Amatea, Cholewa, \& Mixon, 2012; Boethel, 2003; Harris \& Goodall, 2008; McDermott, 2008; Norris, 2010). The importance of relationship with families pervades this literature (Amatea, 2009; Beltran, 2012; 
Boethel, 2003; Calabrese Barton et al., 2004; Hiatt-Michael, 2007; Kearney, McIntosh, Perry, Dockett, \& Clayton, 2014; Olender, Elias, \& Mastroleo, 2010). Ramos (2007) states, 'as the faces of parents change, then so should the ways in which we conceptualize parent involvement and home-school connections' (p. 33). This literature focused on working with families of diverse learners and/or learners living in poverty, gives us a window into new conceptualizations that hold potential to positively influence the work of teachers with the families of all their learners.

While working with diverse family populations may require different engagement strategies, what is not different is the educational hopes and dreams that families have for their children (Boethel, 2003): 'A review of parent involvement across continents revealed that all parents value quality education for their children. Parents from every culture want the best education that is possible for their children' (Hiatt-Michael, 2007, p. 4). Teachers and parents share this common goal for students, a quality education where the child can flourish. Working together to help students succeed requires that teachers and families collaborate. This collaboration can be quite complex when the teacher and family come from different socioeconomic and/or cultural perspectives.

The current teaching force most often crafts engagement strategies that tend to be middle class, White, and emblematic of European-American values, assumptions, and experiences (Tran, 2014). Calabrese Barton, Drake, Perez, St. Louis, and George (2004), in their study of high-poverty urban families, contend that schools often portray the ideals and beliefs of a capitalist culture and that they view the culture of poor, minority, and linguistically diverse families as subordinate. Much of the literature in this area talks about a power differential between school and family that impacts their ability to understand one another and work together. Work in schools happens in different spaces and within different social, cultural, and political boundaries: 'When the systems of knowledge that inform people's approaches to life are different, it is not surprising that they will also approach and understand things - and each other - differently' (Kearney et al., 2014, p. 339). Kearney and colleagues who work with preschools in rural and remote Indigenous communities in Queensland, Australia, report that historically, relations between Indigenous and non-Indigenous populations are filled with mistrust. That mistrust easily transfers to the educational setting. Schools and classrooms can only be inclusive for families that live within differing systems when they are intentional about working at the intersection of the school's perspective and the family's perspective (Calabrese Barton et al., 2004; Kearney et al., 2014). Harris and Goodall (2008) state it this way: 'parental engagement is going to be possible with certain groups only if major efforts are made to understand the local community, and if the relationship is perceived to be genuinely two-way' (p. 286). While traditional parent engagement research fails to recognize that engagement is a social and relational process (Calabrese Barton et al., 2004; Kearney et al., 2014), emphasis on two-way relationships with diverse and economically challenged populations is prevalent in the related literature. Kearney et al. (2014) note that these relationships serve as the precursor of positive educational experiences for families with the school.

Despite the clear presence that teacher/family relationships have in the standards, the literature that focuses on diverse families indicates that initiating and maintaining teacher/family relationships is a complex and challenging task. This is an area of proficient teaching where the slogan, just do it, is insufficient, and where the careful development of teacher knowledge and skill is required. An exploration of how culturally responsive relationships are built offers an important window into the key concepts and strategies that teachers need to develop and apply in their work with families. These notions provide an agenda for teacher development. 


\section{Teacher development: a next step}

Amatea (2009) contends that teacher preparation programs continue to prepare teachers with narrow conceptions of the role that families can have in students' education.

There is also a need for school administrators and professional development staffers to further prepare in-service teachers in current collaboration and engagement paradigms and research (Sewell, 2012). Teacher development needs to begin with the key concepts and strategies to build meaningful relationships with families. Relationships lay the foundation for the collaborative work that teachers will do to engage families in advancing childrens' achievement. The remainder of this article discusses six key concepts and strategies, drawn from the literature, for building relationships with families and provides suggestions for beginning the process of collaboration.

\section{Knowledge of child and family}

A first step in culturally responsive relationships is for teachers to study and gain knowledge of the child, the family, and their culture and language. Making personal contact can open the door for teachers to learn about their students' families (Ferguson, 2007). Home visits are one strategy that provides the teacher with a rich source of information about the child and family (Hiatt-Michael \& Purrington, 2007). Ramos (2007) suggests another potential strategy, community-based literacy walks. With this approach, the teacher ventures into the community where their students live and has opportunity to become familiar with community resources. This activity offers teachers the opportunity to see and learn about the places that are part of the child's life. Teachers can use their newly acquired knowledge to build meaningful connections between the school and the home.

\section{Teachers take the lead}

Teachers must reach out to families, rather than expecting families to come to them. Teachers bear the responsibility for taking the lead in the building of relationships with families (Amatea, 2009; Boethel, 2003; Calabrese Barton et al., 2004; Ferguson, 2007; Hiatt-Michael, 2007; Kearney et al., 2014). When schools are hospitable to families and teachers pursue families, a new culture can emerge (Ferguson in Hiatt-Michael, 2007). This culture welcomes interaction between family and teacher and can create an open door for further interaction.

Amatea (2009) suggests that teachers begin by reaching out to families and making themselves known, sharing who they are and indicating what they have in common with the family. Making personal contact seems to be key, being sure to share in culturally appropriate ways for each family. In these interactions, teachers should make it clear that they personally know the family's child (Dyches, Carter, \& Prater, 2011). When a family feels that they are welcome and that the teacher knows their child, they are more likely to reciprocate in sharing about their child. When teachers reach out in culturally responsive ways, the beginnings of a relationship ensue.

\section{Shared commitment to the child's well-being and success}

Two-way relationships are built when both parties bring equally significant information to the relationship. In the case of teachers and families, honoring the expertise that each party brings and finding the common ground or shared commitment can strengthen the relationship. Teachers and families are both completely committed to the growth and well-being of the child (Amatea, 2009; Boethel, 2003; Kearney et al., 2014; Tran, 2014). This is a wonderful place to start. Teachers need to capitalize and name this common ground that they share with families. Consider, for example, 
making time to listen to a caregiver share about the specific strengths and talents they have observed in their child. Teachers may be able to support the caregiver's observations with specific examples from school. When these shared commitments are acknowledged, families may be more willing to explore challenging issues related to their child's growth and well-being.

\section{Strengths-based perspective}

Successful relationships are fostered when teachers identify and build upon the strengths of each family in the educative process (Tran, 2014). Every child comes from a family with unique life experiences and strengths. Honoring what families bring to the school-home partnership helps to deepen the relationship between teacher and families. As an example, Hiatt-Michael (2007) says that families bring funds of knowledge about the child that are invaluable to the teacher. Teachers should take steps to learn about each family and the funds of knowledge represented in their home setting (Dyches et al., 2011). This knowledge can empower teachers to make curricular connections to the home environment and increase meaning around the learning for students and families. A strength-based perspective is rooted in a belief that parents bring needed expertise regarding their child's education; they are a child's first and most influential teacher. Amatea (2009) suggests that an effective relationship building strategy is for teachers to routinely ask parents and families to share their observations and expertise about their child. This practice honors the role that families play in the pursuit of the growth of their child.

\section{Building trust}

Trust is a foundational component of any relationship. Olender et al. (2010) highlight the particular benefits in a family/teacher relationship:

The most valuable parental benefit of having a positive relationship with their child's teacher is the development of trust that emerges from this relationship. As parents' trust in their child's teacher increases, their anxieties tend to decrease. As their anxieties decrease, their willingness to support the efforts of the teacher increases. This, in turn, increases their child's academic achievement. (p. 5)

Teachers need to recognize that developing trust in relationships takes time. A key strategy that teachers can use is a purposeful plan for multiple interactions with families over time. The interactions can include but are not limited to phone calls, emails or personal contact reporting on a positive aspect of the child's work in class, a brief note reporting on an encouraging social interaction involving the child, an electronic photo of a child's work, or a personal response to a child's achievement on an assignment. The possibilities are endless. While these suggestions are not new ideas, the purposeful nature of multiple interactions as related to trust building is a significant concept. Frequent interactions over time lead to the building of trusting relationships.

\section{Reciprocal communication}

Strong, two-way communication is vital for healthy relationships and contributes to creating a welcoming sense of community between the school and home (Graham-Clay, 2005). Two-way communication happens when families and teachers engage in mutual dialogue. Regrettably, many teachers never receive training in the skill set that supports effective communication (GrahamClay, 2005; Lawrence-Lightfoot, 2004). Caspe (2003) advocates for professional skill development in this area. 
Communication occurs not only through words, but also by tone, body language, facial expression, and physical space (Olender et al., 2010). Leibforth and Clark (2009) offer a small set of skills that can be taught and practiced to build effective communication. The skill set they describe is designed to enhance communication and contribute to the building of strong relationships. Attentive listening is the first skill; it corresponds with showing respect and building trust. When a listener is intent on hearing what another has to say, it sends the message that the listener is genuinely interested in what is being said. A listener's time shows respect and care for the one who is speaking. Olender et al. (2010) say that attentive listening involves making eye contact, paying attention to words and non-verbal cues, being aware of feelings associated with words, and cueing the speaker that they have been heard by saying something that indicates they have been listening.

A second skill is paraphrasing and/or summarizing the conversation. Paraphrasing and summarizing entail the listener using some of their own words in tandem with important main words by the speaker to clarify what is being communicated. It is a chance to 'check in' to see if you, as listener, clearly understand the message being sent (Leibforth \& Clark, 2009). This demonstration of attention to a family member can help create a bond between both parties.

A third skill involves asking appropriate questions. Carefully crafted questions encourage the speaker to continue sharing important information as well as conveying respect and interest in the speaker: 'Open, or inviting questions start with words such as what and how. Closed, or noninviting, questions start with the word why' (Leibforth \& Clark, 2009, p. 210). A teacher's choice of words, through appropriate questioning, have the potential to value the speaker and encourage them to further expand their thoughts.

Finally, using constructive feedback is an important skill to apply in relationships with families (Leibforth \& Clark, 2009). Families are hungry to know how their child is doing both academically and socially. When providing constructive feedback teachers should name the issue or behavior that they will discuss, share their professional observation, and then offer a possible strategy for addressing the issue or behavior. It is important for the teacher to use I statements in the feedback process. Then, invite the family to share their perspective. Next steps should take into account both the teachers' professional feedback and the families' perspective. If done well, constructive feedback can build trust and enhance the relationship between the teacher and the family.

When these key relationship concepts and skills are developed and put to use, a relational foundation forms. This foundation sets the stage for collaborative work to ensue, thus facilitating student growth and well-being.

\section{Stepping into collaborative work}

When strong teacher/family relationships are established, teachers can begin to facilitate collaborative work. Amatea (2009) suggests that teachers start by building opportunities for families and teachers to collaborate around non-problematic issues. An example would be engaging parents in the planning and execution of traditional activities for children and the classroom. The goal here is to practice a positive working relationship. As these initial collaborative opportunities are exercised, then teachers can begin to move the relationship into collaboration around the academic success and well-being of the child. These interactions will often involve problem solving around an academic or behavioral issue with the child. Two-way partnerships will require co-decisionmaking roles for both the teacher and the family, with each party bringing their knowledge and expertise (Amatea, 2009). A collaborative approach assigns work to the family and the teacher on behalf of the child's success. It is this type of engagement that makes a difference in the achievement of students. 


\section{Conclusion}

Dr Nancy Golden (2015), a US Chief Education Officer, wrote 'authentic partnerships with families represent some of the greatest sources of untapped capacity for delivering on the promise of opportunity for each of our students' (p. 1). Equipping teachers with the key concepts and strategies to build meaningful relationships with families lays the foundation for the kinds of collaborative work that impact student achievement. Teacher development in this area holds promise to improve professional practice in our work with families. Building authentic relationships with families must become a priority for every teacher and school administrator.

\section{References}

Amatea, E. S. (2009). Building culturally responsive family-school relationships. Upper Saddle River, NJ: Pearson Education.

Amatea, E. S., Cholewa, B., \& Mixon, K. A. (2012). Influencing preservice teachers' attitudes about working with low-income and/or ethnic minority families. Urban Education, 47, 801-834.

Beltran, E. (2012). Preparing young Latino children for school success: Best practices in family engagement (policy brief 24). Washington, DC: National Council of La Raza.

Boethel, M. (2003). Diversity: School, family, \& community connections. Austin, TX: National Center for Family and Community Connections with Schools, Southwest Educational Development Laboratory. Retrieved from http://www.sedl.org/pubs/catalog/items/fam35.html.

Calabrese Barton, A., Drake, C., Perez, J., St. Louis, K., \& George, M. (2004). Ecologies of parental engagement in urban education. Educational Research, 33, 3-12. Retrieved from http://www.jstor.org.georgefox.idm.oclc.org/stable/3699858.

Caspe, M. S. (2003). How teachers come to understand families. School Community Journal, 13, 115-131.

Casper, V. (2011). Terms of engagement: Preparing pre-service teachers to form authentic partnerships with families and communities. Education as Change, 15(Suppl. 1), S5-S19.

Christenson, S. L. (2000). Families and schools: Rights, responsibilities, resources, and relationships. In R. C. Pianta, \& M. J. Cox (Eds.), The transition to kindergarten (pp. 143-177). Baltimore, MD: Paul H. Brookes Publishing Co.

Christenson, S. L., \& Reschly, A. (2010). Handbook of school-family partnerships. New York, NY: Routledge.

Dorfman, D., \& Fisher, A. (2002). Building relationships for student success: School-family-community partnerships and student achievement. Portland, OR: Northwest Regional Educational Laboratory.

Dyches, T. T., Carter, N. J., \& Prater, M. A. (2011). A teacher's guide to communicating with parents: Practical strategies for developing successful relationships. Upper Saddle River, NJ: Pearson Education.

Epstein, J. L. (2011). School, family, and community partnerships: Preparing educators and improving schools (2nd ed.). Boulder, CO: Westview Press.

Epstein, J. L., \& Sanders, M. (2006). Prospects for change: Preparing future educators for school, family and community partnerships. Peabody Journal of Education, 81, 81-120.

Ferguson, C. (2007). Building meaningful relationships; caring and respect. In D. B. Hiatt-Michael (Ed.), Promising practices for teachers to engage families of English language learners (pp. 11-31). Charlotte, NC: Information Age Publishing.

Golden, N. (2015, May 29). From the desk of the Chief Education Officer. OEIB Bulletin. Copy in possession of author.

Graham-Clay, S. (2005). Communicating with parents: Strategies for teachers. School Community Journal, $15,117-130$.

Halgunseth, L., Peterson, A., Stark, D. R., \& Moodie, S. (2009). Family engagement, diverse families, and early childhood education programs: An integrated review of the literature. Washington, DC: NAEYC and Pre-K Now. Retrieved from www.naeyc.org/files/naeyc/file/ecprofessional/EDF_Literature $\% 20$ Review.pdf.

Harris, A., \& Goodall, J. (2008). Do parents know they matter? Engaging all parents in learning. Educational Research, 50, 277-289. 
Harvard Family Research Project. (2006). Is teacher preparation key to improving teacher practices with families? What are the alternatives? FINE Network. Retrieved from http://www.hfrp.org/familyinvolvement/fine-family-involvement-network-of-educators/member-insights/is-teacher-preparationkey-to-improving-teacher-practices-with-families-what-are-the-alternatives.

Henderson, A. T., \& Mapp, K. L. (2002). A new wave of evidence: The impact of school, family, and community connections on student achievement. Austin, TX: National Center for Family \& Community Connections with Schools Southwest Educational Development Laboratory.

Henrich, C. C., \& Gadaire, D. M. (2008). Head Start and parent involvement. Infants and Young Children, $21,56-69$.

Hiatt-Michael, D. B. (2001). Preparing teachers to work with parents. Washington, DC: ERIC Clearinghouse on Teaching \& Teacher Education (ERIC Document Reproduction Services).

Hiatt-Michael, D. B. (2007). Promising practices for teachers to engage families of English language learners. Charlotte, NC: Information Age Publishing.

Hiatt-Michael, D. B. (Ed.). (2010). Promising practices to support family involvement in schools. Charlotte, NC: Information Age Publishing.

Hiatt-Michael, D. B., \& Purrington, L. (2007). Reaching out from the classroom to the families. In D. B. Hiatt-Michael (Ed.), Promising practices for teachers to engage families of English language learners (pp. 11-31). Charlotte, NC: Information Age Publishing.

Interstate New Teacher Assessment and Support Consortium. (2011). InTASC model core teaching standards: A resource for state dialogue. Retrieved from http://www.ccsso.org/intasc.

Kearney, E., McIntosh, L., Perry, B., Dockett, S., \& Clayton, K. (2014). Building positive relationships with Indigenous children, families and communities: Learning at the cultural interface. Critical Studies in Education, 55, 338-352.

Lawrence-Lightfoot, S. (2004). Building bridges from school to home. Instructor, 114, 24-28.

Leibforth, T., \& Clark, M. (2009). Getting acquainted with students' families. In E. S. Amatea (Ed.), Building culturally responsive family-school relationships (pp. 201-230). Upper Saddle River, NJ: Pearson Education.

Mantzicopoulos, P. (2003). Flunking kindergarten after head start: An inquiry into the contribution of contextual and individual variables. Journal of Educational Psychology, 95, 268-278.

Markow, D., Macia, L., \& Lee, H. (2013). The MetLife survey of the American teacher: Challenges for school leadership. New York, NY: MetLife Corporation. Retrieved from https://www.metlife.com/assets/cao/ foundation/MetLife-Teacher-Survey-2012.pdf.

McDermott, D. (2008). Developing caring relationships among parents, children, schools, and communities. Thousand Oaks, CA: SAGE.

McWayne, C., Hampton, V., Fantuzzo, J., Cohen, H. L., \& Sekino, Y. (2004). A multivariate examination of parent involvement and the social and academic competencies of urban kindergarten children. Psychology in the Schools, 41, 363-377.

MetLife Corporation. (2011). MetLife survey of the American teacher: Teachers, parents and the economy. Retrieved from http://files.eric.ed.gov/fulltext/ED530021.pdf.

Miller, G., Lines, C., Sullivan, E., \& Hermanutz, K. (2013). Preparing educators to partner with families. Teaching Education, 24, 150-163.

National Board for Professional Teaching Standards. (1989). What teachers should know and be able to do. Retrieved from http://www.nbpts.org/five-core-propositions.

National Board for Professional Teaching Standards. (2012a). Early childhood generalist (3rd ed.). Retrieved from http://boardcertifiedteachers.org/certificate-areas.

National Board for Professional Teaching Standards. (2012b). Middle childhood generalist (3rd ed.). Retrieved from http://boardcertifiedteachers.org/certificate-areas.

Norris, K. E. (2010). Beyond the textbook: Building relationships between teachers and diversely-structured families. Multicultural Education, 18, 48.

Olender, R., Elias, J., \& Mastroleo, R. (2010). The school-home connection, forging positive relationships with parents. Thousand Oaks, CA: Corwin. 
Patte, M. M. (2011). Examining pre-service teacher knowledge and competencies in establishing familyschool partnerships. School Community Journal, 21, 143-159. Retrieved from http://www.adi.org/ journal/2011fw/FallWinter2011.pdf.

Ramos, R. (2007). Developing an understanding of families and community. In D. B. Hiatt-Michael (Ed.), Promising practices for teachers to engage families of English language learners (pp. 11-31). Charlotte, NC: Information Age Publishing.

Sewell, T. (2012). Are we adequately preparing teachers to partner with families? Early Childhood Education Journal, 40, 259-263.

Tran, Y. (2014). Addressing reciprocity between families and schools: Why these bridges are instrumental for students' academic success. Improving Schools, 17, 18-29.

Van Voorhis, F. L., Maier, M. F., Epstein, J. L., \& Lloyd, C. M. (2013). The impact of family involvement on the education of children ages 3 to 8: A focus on literacy and math achievement outcomes and social-emotional skills. Retrieved from http://www.mdrc.org/publication/impact-family-involvementeducation-children-ages-3-8.

Weiss, H. B., Caspe, M., \& Lopez, M. E. (2006). Family involvement in early childhood education. Cambridge, MA: Harvard Family Research Project. 